\title{
APPENDIX III. A MARINE GEOPHYSICAL SURVEY (SITE 216 DSDP) ON THE NINETYEAST RIDGE, EQUATORIAL INDIAN OCEAN ${ }^{1}$
}

\author{
Bhoopal R. Naini and Stephen L. Eittreim, Lamont-Doherty Geological Observatory, \\ Columbia University, Palisades, New York
}

\begin{abstract}
This study has revealed that the Ninetyeast Ridge at this location is made up of linear north-south-trending topography with isolated highs on the crest. Free-air gravity anomalies follow the topographic trend closely. Magnetic lineations are poor and define roughly a northeast-southwest pattern. Seismic stratigraphy consists of two to three well-stratified layers underlain by basement. Seismic refracted arrivals recorded on a sonobuoy reveal occurrence of velocities similar to layer 2 and layer 3 (oceanic layer) at depths of 4.09 and $7.13 \mathrm{~km}$, respectively. Dredge samples from the eastern escarpment of the ridge are dated as Cretaceous-Eocene.
\end{abstract}

\section{INTRODUCTION}

A detailed site survey of an approximately $1^{\circ} \times 1^{\circ}$ over the Ninetyeast Ridge, equatorial Indian Ocean (Figure 1) was carried out by Lamont-Doherty Geological Observatory in March 1971 by R/V Robert D. Conrad during its fourteenth voyage. The synposis of the track for this site survey is shown in Figure 2. This region was selected on the basis of the findings of an earlier reconnaissance cruise of the same vessel in June 1965. The reconnaissance survey has indicated the ridge here to consist of a double crest with a more typical asymmetric shape (Figure 3), covered by sediment up to $0.6 \mathrm{sec}$ thick ( $0.1 \mathrm{sec}$ two-way vertical reflection time corresponds approximately to 100 -meterthick sediment, assuming a mean velocity of $2.0 \mathrm{~km} / \mathrm{sec}$ ). This site was drilled subsequently (DSDP Hole 216 and 216A; von der Borch and Sclater et al., 1972) during February 18-21, 1972.

The Ninetyeast Ridge has been described as "perhaps the longest and straightest ridge so far discovered in any ocean," that "has been traced from $10^{\circ} \mathrm{N}$ to $32^{\circ} \mathrm{S}$ " (Heezen and Tharp, 1965). However, recently it has been suggested that this ridge is made up of en echelon mountainous masses (Bowin, 1973) and consists of a series of shoal regions separated by deep channels which once might have been a chain of coral atolls that are now submerged (McKenzie and Sclater, 1971). The extension of the ridge up to $15^{\circ} \mathrm{N}$, as a buried feature, beyond the present-day topographic relief has been reported by Naini and Leyden (in press). The ridge is flanked by basins on either side, which are covered by sediment that is thin on the south and reaches greater than $2.5 \mathrm{sec}$ thick towards north over the Ganges Cone (Ewing et al., 1969). It appears that the topography of the ridge may somewhat obstruct passage of sediment from the Ganges Cone (called the Bengal Fan in this volume) into the Wharton Basin on the east.

\section{TOPOGRAPHY}

A detailed bathymetric map of the survey region in corrected meters along the ship's track, contoured at 100-meter intervals is given in Figure 4. An overall north-south trending linear pattern with possible en echelon features is apparent from this map. The crestal region of the ridge here has isolated peaks. The flank topography is nearly linear and continuous, with the eastern flank much steeper than the western flank. The crest in the south is a broad shoaler region with an isolated peak approximately in the center. The total relief in this region is of the order of 2000 meters.

\section{GRAVITY}

The free-air gravity anomalies in the study area are contoured at 5-mgal intervals (Figure 5). It is noticeable from this map that there is a close correlation between the local gravity field and the local topography. The ridge here has highest free air values over the crest reaching a maximum of about $45 \mathrm{mgal}$. The gravity anomalies decrease over the flanks with a steeper gradient over the eastern flank than the western flank. The total range of the free-air values from flank to the ridge crest is of the order of $55 \mathrm{mgal}$. The positive anomalies of ridge crest form part of a continuous belt of positive anomalies associated with the Ninetyeast Ridge (Talwani and Kahle, in press). In addition, the negative anomalies identified in the region of the ridge flank are also part of a belt of negative anomalies on either side of Ninetyeast Ridge.

\section{MAGNETICS}

A regional magnetic anomaly pattern over the Ninetyeast Ridge and in the Wharton Basin has not been delineated as of yet. In the central Indian basin to the west of Ninetyeast Ridge, north-south sea-floor spreading 


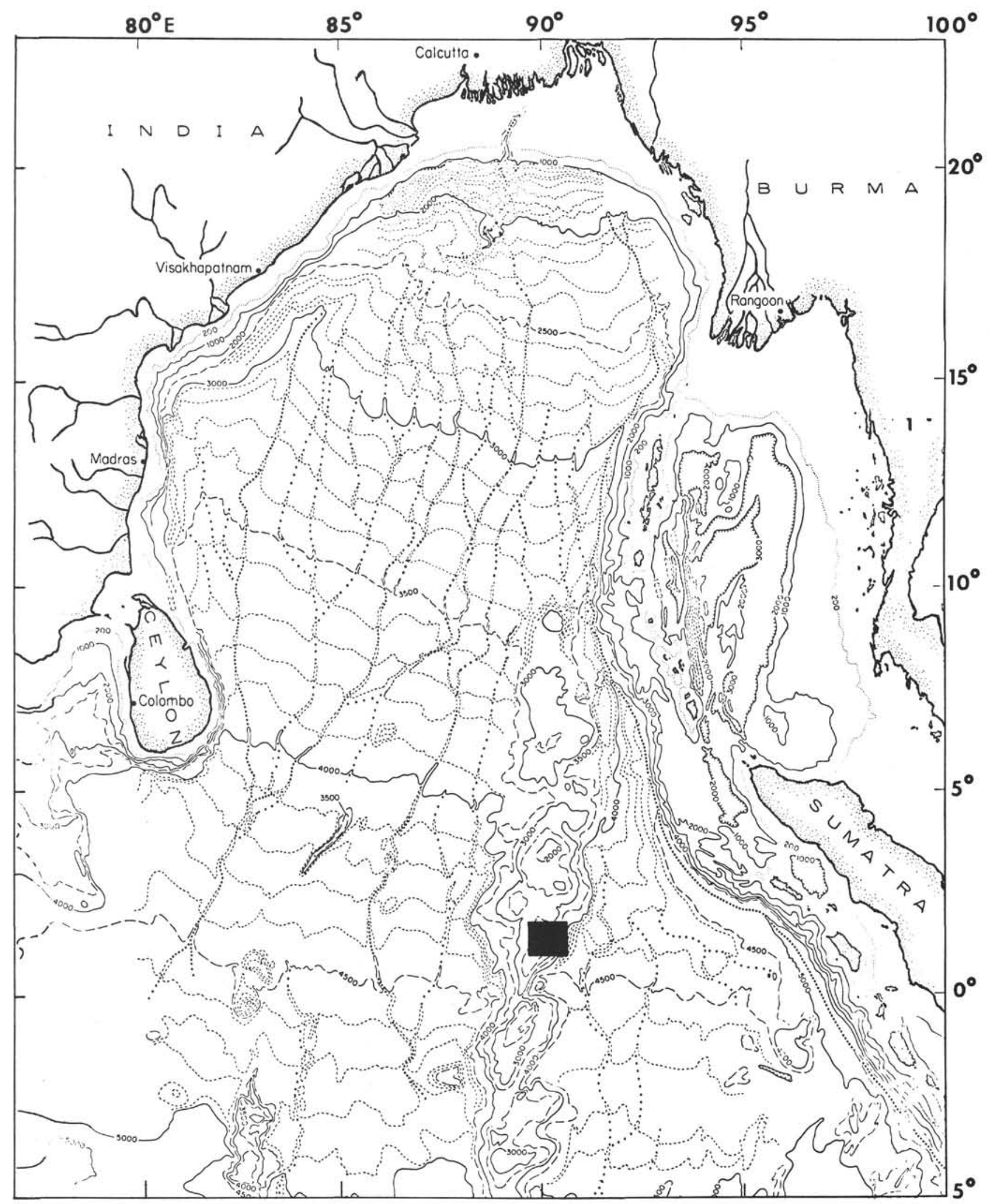

Figure 1. Location of the survey area marked as black square in the northeastern Indian Ocean. Bathymetry from Curray and Moore (1971). 




Figure 2. Track synopsis for the site survey. Time is marked every hour, on the hour with a plus sign. Satellite fixes once a day are marked with day and time; $A B, C D$ etc. identify locations of seismic reflection profiles of Figure 7. Number with prefix $S$ correspond to ship's station and $R$ to sonobuoy recording; whose duration is indicated by parentheses. Black circle (also in Figures 4, 5, 6, and 9) is location of DSDP Holes 216 and $216 \mathrm{~A}$.

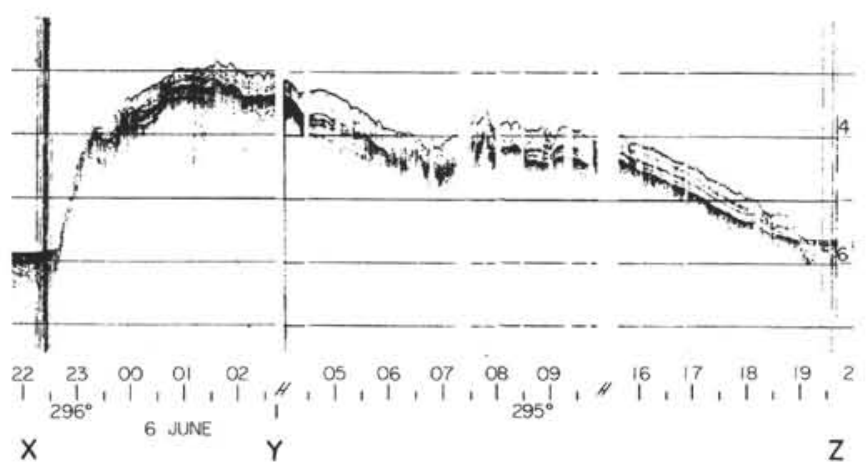

Figure 3. Seismic reflection profile over Ninetyeast Ridge (Conrad 9, 1965). Time and course is marked at the bottom. The coordinates of points $x, y$, and $z$ are $2^{\circ} 29.7^{\prime} N, 88^{\circ} 16.2^{\prime} E ; 1^{\circ} 34.3^{\prime} N, 89^{\circ} 58.6^{\circ} \mathrm{E}$; and $1^{\circ}$ $11.4^{\prime} \mathrm{N}, 90^{\circ} 46.2^{\prime} \mathrm{E}$, respectively.

anomalies up to anomaly 32 of Heirtzler et al. (1968) magnetic time scale have been identified by McKenzie and Sclater (1971). These identified anomalies extend to a northern limit of about $7^{\circ} \mathrm{S}$ just west of the ridge. A detailed magnetic anomaly map of the survey area in terms of residual total intensity magnetic field values along the ship's track contoured at $50 \gamma$ intervals is presented in Figure 6 . The interpretation of a pattern to the anomalies in Figure 6 is not unique; closer track spacing is needed to define it well. However, a northeast-southwest trend appears to be present which is different from that of the topography and gravity. This northeast-southwest trend is similar to that observed further south on the ridge (see Appendix 2).

\section{SEISMIC REFLECTION AND REFRACTION}

Low-frequency airgun seismic reflection profiles (Figures $7 \mathrm{a}-\mathrm{g})$ reveal a stratified sedimentary sequence. This sequence consists of two distinct layers present throughout the area. A third layer is also seen which is not traceable throughout. The entire sequence is well stratified. Each of the first two layers have a maximum of up to $0.2 \mathrm{sec}$ thickness. The third layer, where present, attains a thickness of up to $0.3 \mathrm{sec}$. The sea floor sometimes is made up of highly reflective material giving rise to hyperbolated reflections as evidenced on a $3.5-\mathrm{kHz}$ reflection record (Figure 8). The sedimentary sequence is underlain by a rough acoustic basement. The basement topography shows fault-like offsets, isolated peaks, and approximates an asymmetric dome shape. A sediment isopach map was prepared measuring thicknesses every 10 minutes along the ship's track and contoured at 0.2-sec intervals (Figure 9). The sediment thickness varies between 0.1 to $0.8 \mathrm{sec}$. There are isolated pockets of sediment in basement depressions on the crest of the ridge. The ridge flanks have, in general, a uniform distribution of sediment, which forms a trend parallel or subparallel to that of the local topography. Sediment is sparse to absent over basement highs and the isolated peaks.

Two sonobuoys, R13 and R14, were recorded in this region located at $1^{\circ} 37.6^{\prime} \mathrm{N}, 90^{\circ} 10.5^{\prime} \mathrm{E}$ and $1^{\circ} 29.33^{\prime} \mathrm{N}$, $90^{\circ} 11.3^{\prime} \mathrm{E}$, respectively (see Figure 2 for location). Wide-angle reflections from sonobuoy 13 indicated two sedimentary layers with interval velocities of $2.39 \mathrm{~km} / \mathrm{sec}$ and $2.73 \mathrm{~km} / \mathrm{sec}$ having thicknesses of 0.56 and $0.34 \mathrm{~km}$, respectively. Refracted arrivals from the same buoy yielded apparent velocities of $5.64 \mathrm{~km} / \mathrm{sec}$ and $6.86 \mathrm{~km} / \mathrm{sec}$ for two layers (not seen on the vertical seismic profiler record) at 4.09 and $7.13 \mathrm{~km}$ depth, respectively. These velocities are comparable with the velocities of layer 2 and layer 3 (oceanic layer) in the Indian Ocean, the values of which have been given as $5.19 \pm 0.64 \mathrm{~km} / \mathrm{sec}$ and $6.73 \pm 0.3$ $\mathrm{km} / \mathrm{sec}$, respectively (Shor and Raitt, 1969). The record of this sonobuoy along with the corresponding vertical seismic profiler record is shown in Figure 10. Solutions for sonobuoy 14 , indicate the presence of three sedimentary layers with interval velocities of $1.69 \mathrm{~km} / \mathrm{sec}, 2.35 \mathrm{~km} / \mathrm{sec}$, and $2.64 \mathrm{~km} / \mathrm{sec}$ with corresponding thicknesses of 0.22 $\mathrm{km}, 0.25 \mathrm{~km}$, and $0.35 \mathrm{~km}$, respectively. The three interval velocities and thicknesses found on sonobuoy 14 correspond to those of the sedimentary sequence described earlier. However, on sonobuoy 13 , only two layers are detected. The first layer interval velocity corresponds to a sedimentary column 560 meters thick, which is thicker than the first two layers combined on sonobuoy 14. The second layer of buoy 13 and the third layer of buoy 14 have near similar velocities and thicknesses suggesting the continuity of this layer from one buoy region to the other.

\section{CORING AND DREDGING}

A piston core was taken at station 44 (Figure 2). The 601-cm-long core consisted of foraminiferal ooze, volcanic ash, acidic glass, and biotite. The coarse fraction ranges from $90 \%$ at the top to $60 \%$ at the bottom of the core. The foraminifera at the bottom of the core are of Pleistocene 


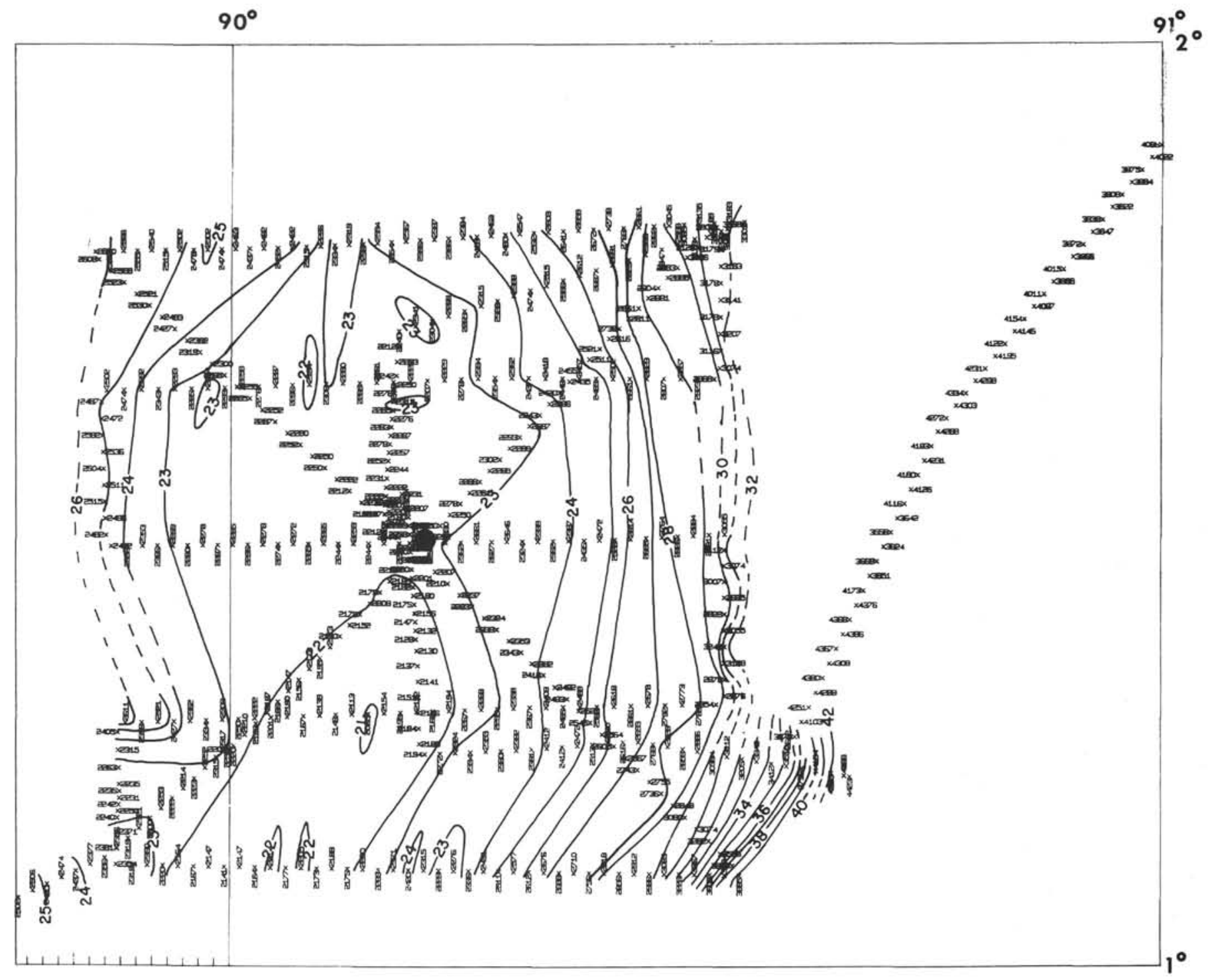

Figure 4. Bathymetric soundings in corrected meters in the survey area plotted along the ship's track contoured in hundreds of meters at 100-meter intervals.

age (T. Saito, personal communication). The eastern escarpment of the ridge was dredged at station 45 . The haul consisted of mudstones, Cretaceous-Eocene limestones containing abundant well crystallized smectite (Venkatarathnam and Biscaye, in press), and altered basalt.

\section{CONCLUSIONS}

This detailed site survey of the Ninetyeast Ridge has revealed that:

1) the ridge consists of linear-north-south-trending topography with isolated highs on the crest and a relatively steeper eastern escarpment.

2) Free-air gravity field trends follow the topographic trends.

3) A poorly defined pattern to the magnetic anomalies trends northeast-southwest.

4) The sediment here is made up of two to three well-stratified layers.
5) The sediment is underlain by acoustic basement with rough topography, exhibiting faults and isolated peaks.

6) Layers with velocities identified with layer 2 and layer 3 occur at depths of 4.09 and $7.13 \mathrm{~km}$, respectively.

7) Dredged samples from the eastern escarpment of the ridge are dated Cretaceous-Eocene.

\section{ACKNOWLEDGMENTS}

We thank Mr. Olav Eldholm and Dr. Yves Lancelot for the critical review of the manuscript and Drs. Roger L. Larson and Anthony B. Watts for helpful comments. We are grateful to Mr. John I. Ewing for his guidance.

This work was supported under grant GA 27281 and 28338 from the National Science Foundation and the Office of Naval Research under contract N00014-67-A0108-0004. 


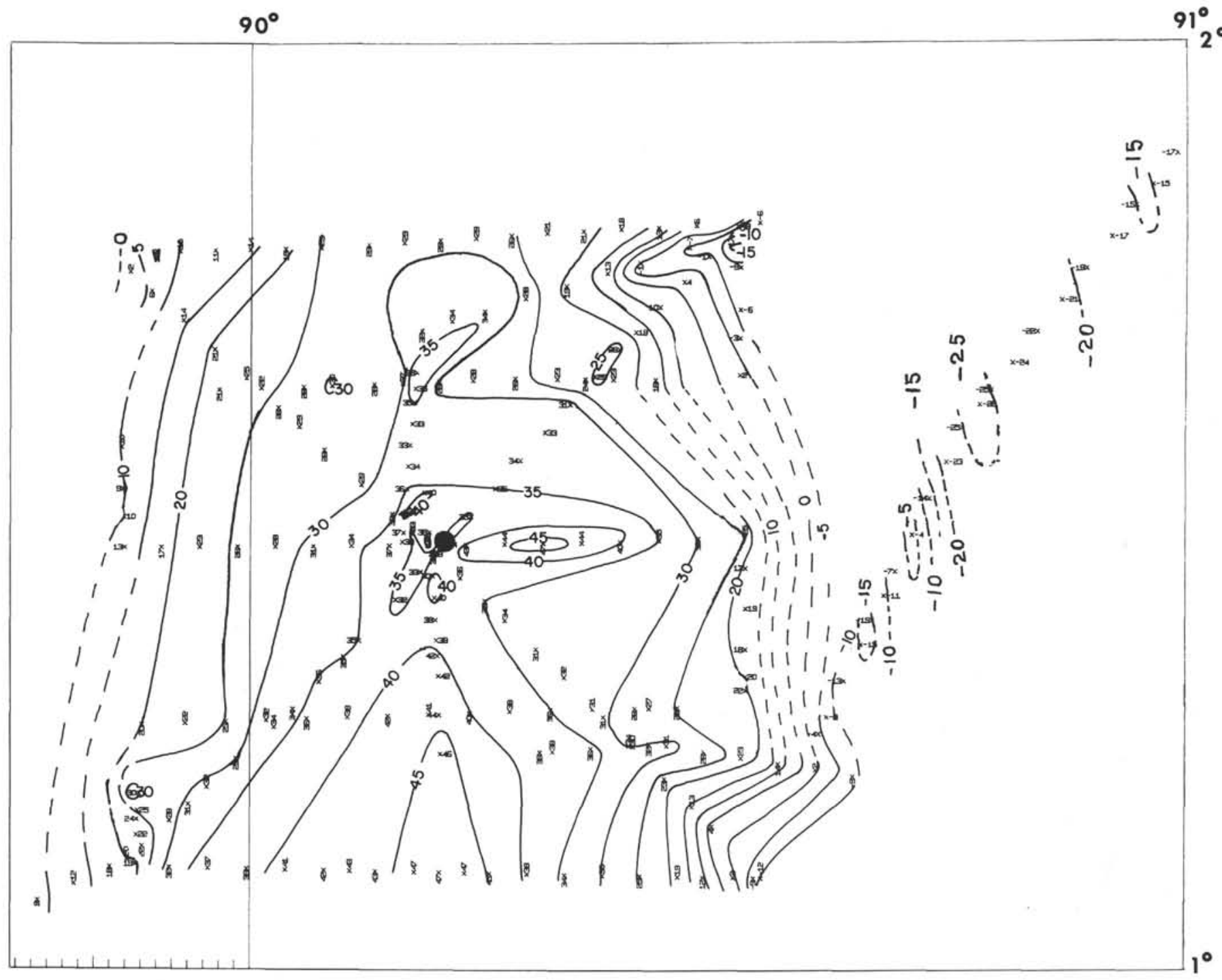

Figure 5. Gravity map of the survey area. Free-air anomaly values plotted along the ship's track and contoured at 5-mgal intervals.

\section{REFERENCES}

Bowin, C. O., 1973. Origin of Ninetyeast Ridge from studies near the equator (Abstract): Am. Geophys. Union Trans., v. 54, p. 330.

Ewing, M., Eittreim, S., Truchan, M., and Ewing, J. I., 1969. Sediment distribution in the Indian Ocean; Deep-Sea Res., v. 16, p. 231-248.

Heezen, B. C., and Tharp, M., 1965. Descriptive sheet to accompany the physiographic diagram of the Indian Ocean. New York (Geol. Soc. Am., Inc.).

Heirtzler, J. R., Dickson, G. O., Herron, E. M., Pitman, W. C., III, and Le Pichon, X., 1968. Marine magnetic anomalies, geomagnetic field reversals, and motions of the ocean floor and continents: J. Geophys. Res., v. 73, p. 2119-2136.

McKenzie, D. and Sclater, J. G., 1971. The evolution of the Indian Ocean since the Late Cretaceous. Geophys. J. Roy. Astro. Soc., v. 25, p. 437-528.
Naini, B. R. and Leyden, R., in press. Ganges Cone: A wide angle seismic reflection and refraction study. J. Geophys. Res.

Shor, G. G., Jr. and Raitt, R. W., 1969. Explosion seismic refraction studies of the crust and upper mantle in the Pacific and Indian oceans. In The earth's crust and upper mantle, Geophys. Mono. 13: Hart, P. J. (Ed.), Washington (Am. Geophys. Union), p. 225-230.

Talwani, M. and Kahle, H. G., in press. Free-air gravity charts of the Indian Ocean: In The atlas of geology and geophysics of the international Indian Ocean Expedition. Udintsev, G. (Ed.).

Venkatarathnam, K. and Biscaye, P. E., in press. Clay mineralogy and sedimentation in the eastern Indian Ocean: Deep-Sea Res.

von der Borch, C. C., Sclater, J. G., Gartner, S., Jr., Hekinian, R., Johnson, D. A., McGowran, B., Pimm, A. C., Thompson, R. W., and Veevers., J. W., 1972. Deep Sea Drilling Project, Leg 22: Geotimes, v. 17, p. 15-17.

Curray, J. R., and Moore, D. G., 1971. Growth of the Bengal deep-sea fan and denudation of the Himalayas: Geol. Soc. Am. Bull., v. 82, p. 563-592. 


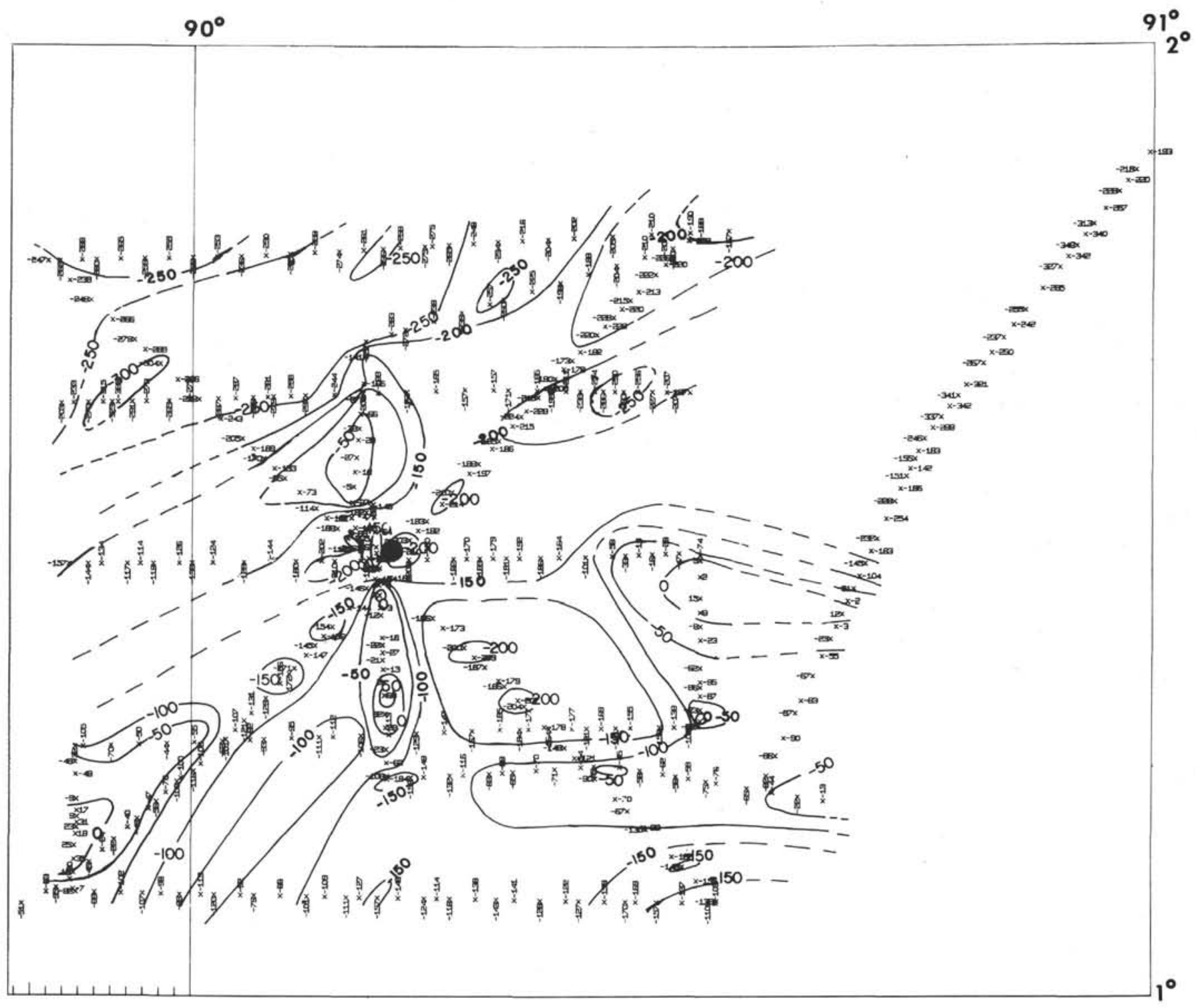

Figure 6. Residual total intensity magnetic field values plotted along the ship's track in the survey area and contoured at 50gamma intervals. 

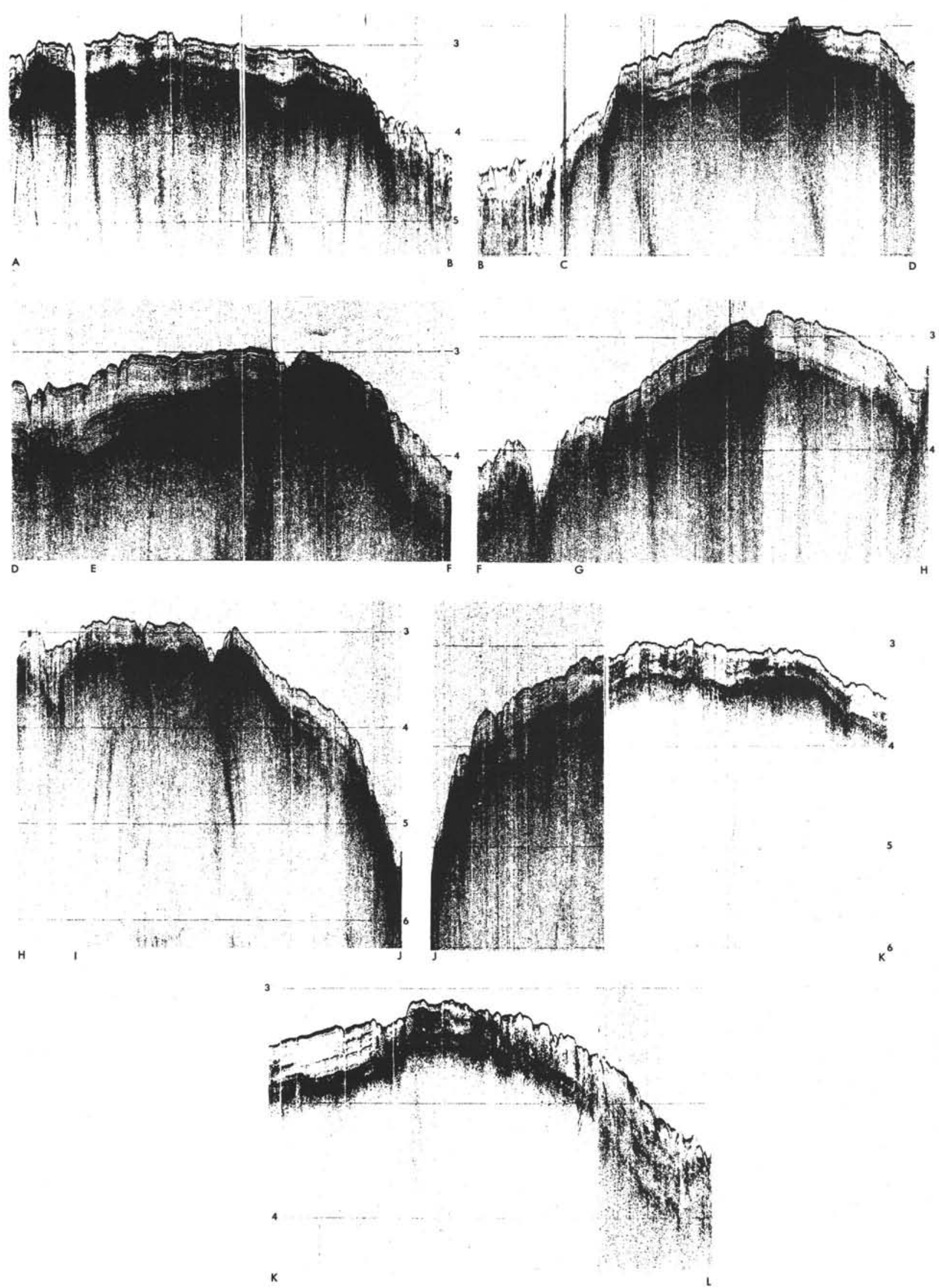

Figure 7a-g. Low-frequency airgun seismic reflection profiles along different sections (Figure 2) showing various features described in the text. Vertical scale is two-way travel time in seconds. 


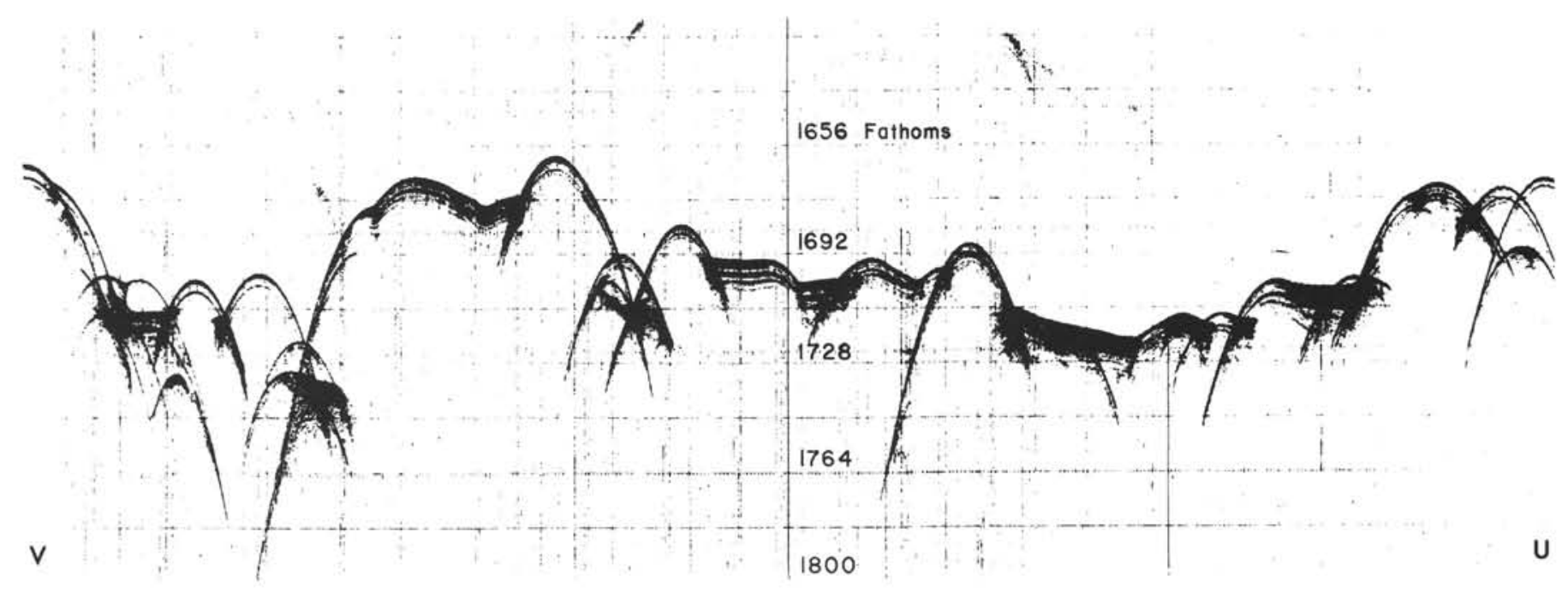

Figure 8. 3.5- $\mathrm{kHz}$ reflection record along section UV (Figure 2) showing the reflective nature of the bottom.

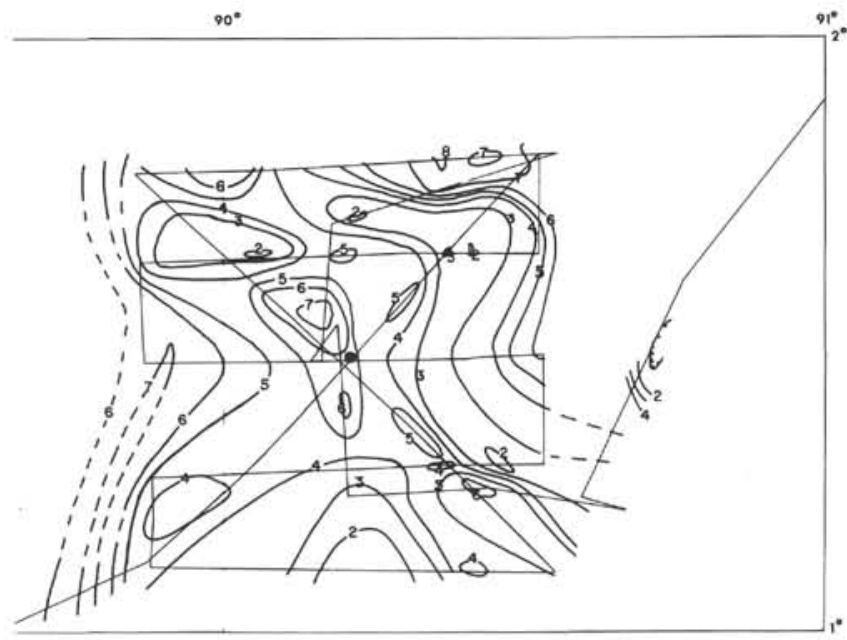

Figure 9. Sediment isopach map of the survey area based on readings of travel time through sediment at 10-min intervals and contoured in tenths of seconds two-way travel time. Hachures are towards basement outcrop. 

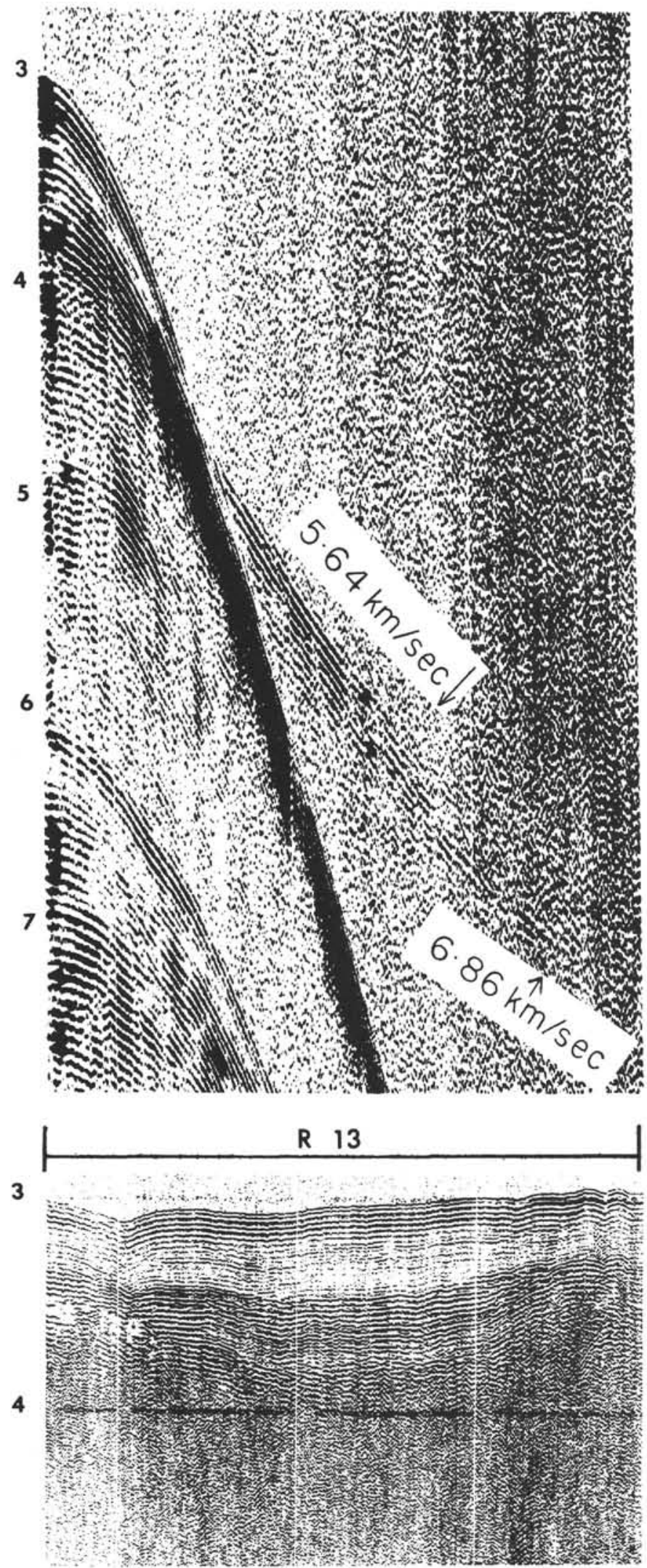

Figure 10. Sonobuoy record, R13 (Figure 2) showing wide-angle reflections (hyperbolae) and refracted arrivals identified by their apparent velocities. The vertical reflection record corresponding to the sonobuoy record is at the bottom. Vertical scale is two-way travel time in seconds. Note, the first water multiple arriving about 6 sec. 